\title{
Chemical Profile and Biological Activities of Essential oil of Aerial parts of Artemisia monosperma Del. Growing in Libya
}

\author{
Soheir Mohamed El Zalabani' Soad Hanna Tadros ${ }^{1}$, Abeer Mohamed El Sayed ${ }^{*}$, Areej Almaktouf Daboub ${ }^{2}$ and \\ Amany Amen Sleem ${ }^{3}$
}

\section{Soheir Mohamed El Zalabani' Soad Hanna Tadros ${ }^{1}$, Ábeer Mohamed El Sayed ${ }^{*}$, Areej Almaktouf Daboub ${ }^{2}$ and Amany Amen Sleem ${ }^{3}$}

'Department of Pharmacognosy, College of pharmacy, CairoUniversity, Cairo, EGYPT.

${ }^{2}$ Department of Pharmacognosy, College of pharmacy, AL Zawia University, LIBYA.

${ }^{3}$ Pharmacology Department, National Research Center, El-Dokki, Giza, EGYPT.

\section{Correspondence}

Abeer Mohamed Ali El Sayed, Pharmacognosy Department, College of Pharmacy, Cairo University, Kasr El-Einy Street, 11562, Cairo, EGYPT. Tel.: +20224707394 - +201112874103

E-mail: galbd_abeer@yahoo.com Abeer.ali@pharma.cu.edu.eg

History

- Submission Date: 09-01-2017

- Review completed: 02-03-2017

- Accepted Date: 15-03-2017.

DOI : 10.5530/pj.2017.4.92

Article Available online

http://www.phcogj.com/v9/i4

\section{Copyright}

(c) 2017 Phcog.Net. This is an openaccess article distributed under the terms of the Creative Commons Attribution 4.0 International license.

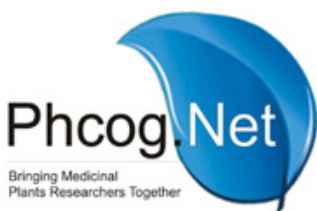

\begin{abstract}
Background: From the bioactivity stand point Artemisia monosperma Del. is reputed to have antispasmodic and anthelmintic properties. Various types of secondary metabolites were reported in A. monosperma plants from different localities. Objective: The current study was planned aiming to investigate the influence of stage of development on the composition, antimicrobial, antiinflammatory and antioxidant activities of the essential oil derived from the aerial parts of the Libyan plants. Material and Methods: A. monosperma volatiles were hydro-distilled from aerial parts of Libyan plants, collected at different stages of growth: before flowering $\left(A_{1}\right)$, and at beginning $\left(A_{2}\right)$ and by the end $\left(A_{3}\right)$ of flowering stage. Yields ranged from 0.16-0.26 ml/100g fresh material ( $A_{3}$, highest). GC/FID and GC/MS analyses were performed. Results: Among 16-20 identified components (97.63-99.00\% of total composition), 11 were common in all samples. $A_{1}$ and $A_{2}$ showed close amounts of hydrocarbons $(63.56$ and $66.55 \%)$, but lesser than $A_{2}(88.36 \%)$; monoterpenoids were mainly represented by sabinene (13.15-22.85\%), $\beta$-pinene (9.00-24.03\%) and $\beta$-cis-ocimene (3.73-12.92\%); while sesquiterpenoids appeared absent. Among oxygenated components $\left(11.29,31.08\right.$ and $35.44 \%$ in $A_{3}, A_{2}$ and $\left.A_{1}\right)$, bornyl acetate was the major monoterpenoid $\left(8.00-31.00 \%\right.$, highest in $\left.A_{1}\right)$; and the sesquiterpenoid, $\beta$-eudesmol (8.01\%) was detected in $A_{2}$ only. Moreover, $A_{2}$ demonstrated significant antifungal effect against Aspergillus fumigatus and Geotricum candidum (MIC 0.98 and $0.24 \mu \mathrm{g} / \mathrm{ml})$. Conclusion: $A_{3}$ exerted the highest anti-inflammatory activity as compared to the other volatiles. A restored the reduced blood GHS level in diabetic animals almost as efficiently as Vitamin $\mathrm{E}$. The antioxidant activity of the volatiles is decreased during the flowering stage, being the highest before flowering $\left(A_{1}\right)$; this could be associated to the decreasing bornyl acetate content of the samples.

Key words: Artemisia monosperma, Essential oil composition, GC-MS, Antimicrobial, Antiinflammatory, Anti-oxidant, Libya.
\end{abstract}

\section{INTRODUCTION}

Genus Artemisia (Asteraceae) comprises about 300 species of broad distribution all over the world. ${ }^{1}$ Moreover, the essential oils derived from several members of this genus have acquired special importance due to their wide variety of applications in folk and modern medicine. ${ }^{2,3}$ The genus is represented in Libya by five species viz., A. arborescens, A. herba-alba, A. judaica, A. campestris and A. monosperma. ${ }^{4}$ The latter is a Saharo-Arabian element and has been reported from Gasar Gharian, Ghat area and Southern Tripolitania. ${ }^{4}$ A. monosperma is a green glabrous shrublet, $50-70 \mathrm{~cm}$ high, with ascending or diffuse stems ending in many flowered panicles; capitula are small (1mm in diameter) with 10-12 tubular florets; the flowering season extends from September to December in most areas. ${ }^{4}$ From the bioactivity stand point $A$. monosperma Del. is reputed to have antispasmodic, anthelmintic and anti-hypertensive properties; ${ }^{5,6}$ its leaves are traditionally used in Jordan to induce abortion $^{7}$ and were found to possess antioxidant, ${ }^{8}$ insecticidal, ${ }^{9}$ anti-malarial ${ }^{10}$ and anticancer activities. ${ }^{11}$ Various types of secondary metabolites were reported in A. monosperma plants from different localities including: coumarins, ${ }^{12,13}$ flavonoids, ${ }^{14-16}$ acetylenes, ${ }^{9,17,18}$ alkaloids, ${ }^{19}$ sesquiterpenoids ${ }^{20}$ and triterpenoids. ${ }^{16}$ However, nothing could be traced in the available literature concerning either the constituents or biological activities of the plant growing in Libya.

\section{MATERIAL AND METHODS}

\section{Plant material}

Aerial parts of A. monosperma Del. $500 \mathrm{~g}$ fresh plant samples were collected from plants growing in Libya (Tobruk Desert) at 3 time intervals: before flowering $\left(A_{1}\right)$, and at the beginning $\left(A_{2}\right)$ and by the end $\left(A_{3}\right)$ of the flowering stage in March, September and late November (2013). The plants were kindly authenticated by Dr. Mohamed El-Gebaly, Botany Specialist.
Cite this article: El Zalabani SM, Tadros SH, El Sayed AM, Daboub AA and Sleem AA. Chemical Profile and Biological Activities of Essential oil of Aerial parts of Artemisia monosperma Del. Growing in Libya. Pharmacog J. 2017;9(4):577-86. 
Voucher specimen 1192013 is kept in the herbarium of the Pharmacognosy Department, Faculty of Pharmacy, Cairo University.

\section{Oil samples}

The essential oils were hydro-distilled from $500 \mathrm{~g}$ fresh plant samples in a Clavenger-type apparatus, isolated and dehydrated. Aliquots $(5 \mu \mathrm{l}$, each) of the prepared oils were, separately, mixed with approximately $1 \mathrm{ml}$ of $\mathrm{CH}_{2} \mathrm{Cl}_{2}$ in auto sampler vials and saved for chromatographic investigation. For biological evaluation solutions $(1 \mathrm{mg} / \mathrm{ml})$ were prepared in DMSO.

\section{Microorganisms, culture media and standard antimicrobial agents}

A set of 12 representative fungal and Gram-positive and -negative bacterial strains were used. The tested microorganisms: Aspergillus fumigatus (RCMB 02564), Candida albicans (RCMB 05035), Geotricum candidum (RCMB 05096), Syncephalastrum racemosum (RCMB 05922), Staphylococcus aureus (RCMB 010027), Staphylococcus epidermidis (RCMB 010024) Streptococcus pyogenes (RCMB 010015) Neisseria gonorrhoeae (RCMB 010076), Proteus vulgaris (RCMB 010085) Klebsiella pneumoniae (RCMB 010093) Shigella flexneri (RCMB 01005420) and Escherichia coli (RCMB 010056) were maintained in the Regional Center for Mycology and Biotechnology (RCMB), Cairo, Egypt. The tested bacteria were sub-cultured on nutrient agar medium (Oxoid laboratories, UK) slopes. Sabouraud's dextrose agar (Oxoid laboratories, UK) was used as culture medium for fungi.

\section{Chemicals and kits}

Penicillin G (Oxoid, UK) and Streptomycin (Oxoid, UK) were used as standard antibacterial agents, meanwhile Amphotericin B (Sigma Chemical Co. St. Louis, Mo.) was used as standard antifungal. Carrageenan: Sigma Co.(0.1 ml of $1 \%$ solution, to induce inflammation), Indomethacin: Epico, A.R.E.(20 mg/kg body weight [b. wt.], as standard anti inflammatory). Alloxan: Sigma Co., Vitamin E (7.5 $\mathrm{mgkg}^{-1} \mathrm{~b}$. wt.) (dla-tocopheryl acetate): Pharco Pharmaceutical Co. Biochemical kits: Biodiagnostic glutathione kit.

\section{Experimental animals}

Adult Sprague-Dawley rats weighing $160 \pm 10 \mathrm{~g}$ were provided from the animal-breeding unit of National Research Center, El-Dokki, Giza, Egypt. They were kept under standard conditions with temperature at $23 \pm 2{ }^{\circ} \mathrm{C}$ and a $12 / 12$ hours light/dark cycle and allowed free access to food and water throughout the experiment. This study was conducted in accordance with the standard guidelines used in handling of the experimental animals and approved by the Institutional Animal Care and Use Committee (IACUC) (No. 9-031), College of Pharmacy, Cairo University.

\section{GC/MS Analysis}

Instrument

Shimadzu capillary gas chromatograph (GC 17A ver.3) directly coupled to mass spectrometer-MS QP5050A and equipped with a capillary column SLB-5ms (30 $\mathrm{m} \times 0.25 \mathrm{~mm}$, film thickness $0.25 \mu \mathrm{m})$.

\section{Operating conditions}

Injection volume, $1 \mu \mathrm{l}$ of $\mathrm{CH}_{2} \mathrm{Cl}_{2}$ solution of tested samples; oven temperature programming: initial temperature, $40{ }^{\circ} \mathrm{C}$ (isothermal for $3 \mathrm{~min}$ ), increased $\left(12^{\circ} \mathrm{C} / \mathrm{min}\right)$ to $180{ }^{\circ} \mathrm{C}$ and hold for $5 \mathrm{~min}$, then further increased to final temperature $240{ }^{\circ} \mathrm{C}\left(40^{\circ} \mathrm{C} / \mathrm{min}\right)$ and maintained for $5 \mathrm{~min}$; injector temperature, $240^{\circ} \mathrm{C}$ and split ratio, set at 1:54; carrier gas, He at flow rate $0.9 \mathrm{ml} / \mathrm{min}$; mass spectrometer, electronic ionization (EI) mode $70 \mathrm{eV}$, scan range 40-500 and transfer line temperature, 230 ${ }^{\circ} \mathrm{C}$.

\section{GC/FID Analysis}

\section{Instrument and operating conditions}

A Shimadzu GC gas chromatograph (GC-17ver.3) coupled with FID detector was used, and detector temperature set at $240^{\circ} \mathrm{C}$. To obtain the same elution order as with GC/MS, simultaneous auto injection was carried out on a duplicate of the same operational conditions.

\section{Identification of Components}

This was performed via comparison of the retention times (Rt) and retention indices (RI, Kovat's indices) of the detected components with those of authentic samples. RIs were computed relative to those of a mixture of a continuous series of $n$-alkane hydrocarbons (C4-C28) analyzed under the same operating conditions as for the samples. Individual components were identified through matching their MS fragmentation patterns with those reported in computerized MS-data bank spectral libraries ${ }^{21-23}$ or reported in the literature. ${ }^{24-25}$ Relative percentages of the identified components were calculated based on GC/FID peak areas without the use of correction factors. Results are compiled in Table 2, Figure $1 \& 2$.
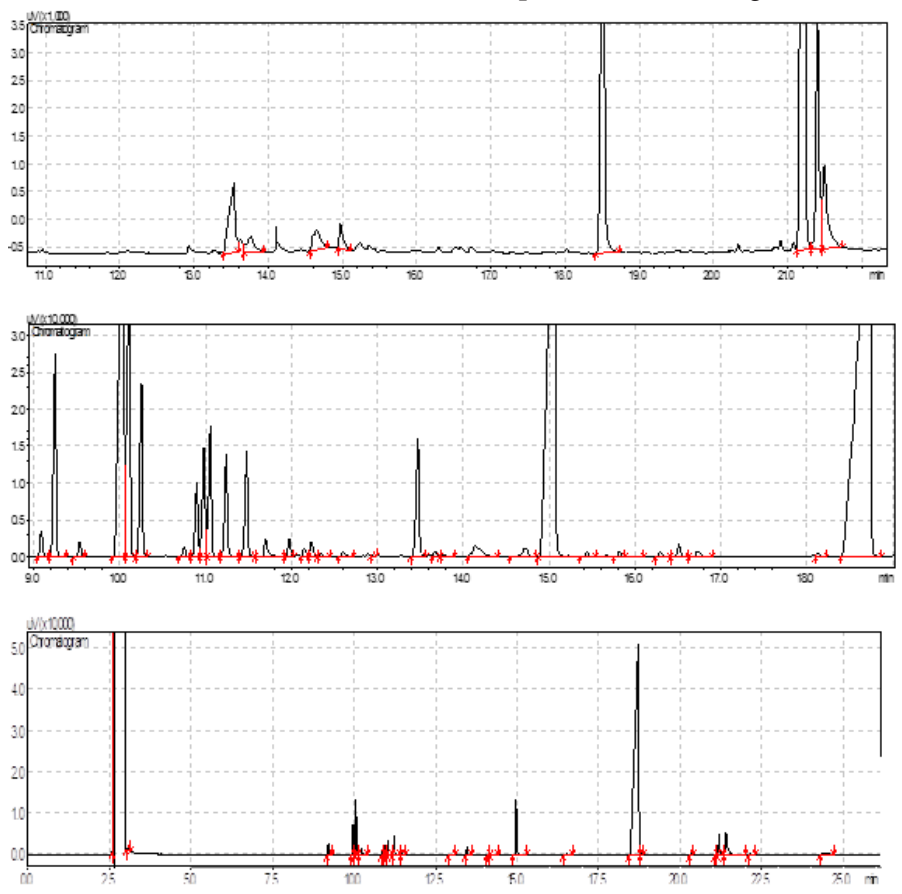

Figure 1: Chromatograms 1, 2 and 3 representing the GC-FID of the essential oils (A1, A2 and A3) samples collected before flowering, and the beginning and end of the flowering stage of $A$. monosperma, respectively.

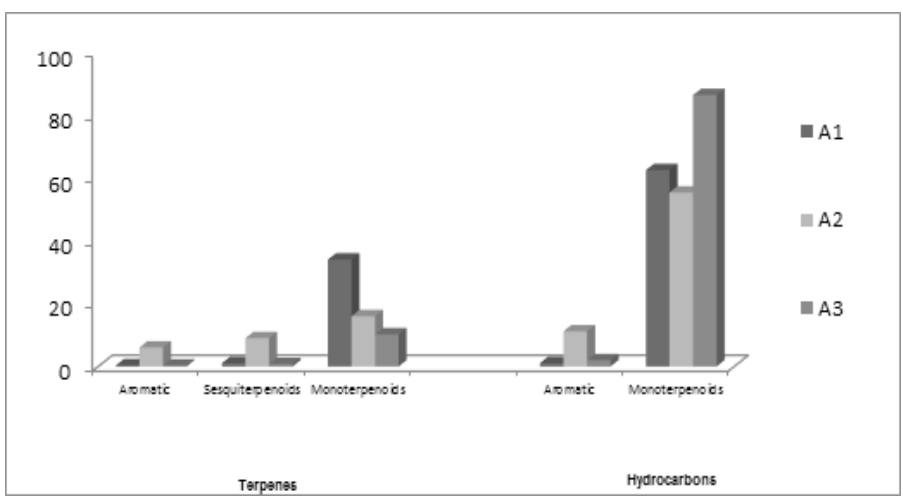

Figure 2: Histogram representing the relative percentages of the different classes of constituents in the essential oils (A1, A2 and A3) samples collected before flowering, and at the beginning and end of the flowering stage of $A$. monosperma, respectively. 
Table 1: Yield and physical characters of the essential oil samples of the aerial parts of Artemisia monosperma

\begin{tabular}{cccc} 
Characteristics & \multicolumn{3}{c}{ Oil samples } \\
\% Yield v/ fresh wt & A1 & A2 & A3 \\
Color & 0.16 & 0.20 & 0.26 \\
Odor & \multicolumn{3}{c}{ Greenish yellow } \\
Optical rotation & \multicolumn{3}{c}{ Aromatic } \\
Specific gravity & +4.7 & +4.5 & +3.9 \\
\hline & 0.914 & 0.911 & 0.901
\end{tabular}

A1, A2 \& A3: samples collected before flowering, and at the beginning and end of the flowering stage.

Table 2: Constituents identified by GC/FID and GC/MS analyses in the essential oil samples of the aerial parts of $A$. monosperma.

\begin{tabular}{|c|c|c|c|c|c|c|c|c|c|}
\hline \multirow[t]{2}{*}{ SN } & \multirow[t]{2}{*}{ Identified Constituents } & \multirow[t]{2}{*}{ Rt } & \multirow[t]{2}{*}{$\mathrm{RI}^{*}$} & \multirow[t]{2}{*}{$\mathrm{RI}^{* *}$} & \multicolumn{3}{|c|}{ Relative percentages } & \multirow[t]{2}{*}{ Mwt } & \multirow[t]{2}{*}{ Formula } \\
\hline & & & & & $\mathrm{A} 1$ & $\mathrm{~A} 2$ & $\mathrm{~A} 3$ & & \\
\hline 1 & $\alpha$-Thujene & 7.52 & 929 & 930 & - & - & 0.76 & 136 & $\mathrm{C}_{10} \mathrm{H}_{16}$ \\
\hline 2 & a-Pinene & 7.67 & 936 & 935 & 6.20 & 1.10 & 5.93 & 136 & $\mathrm{C}_{10} \mathrm{H}_{16}$ \\
\hline 3 & Camphene & 7.98 & 953 & 946 & 0.74 & - & - & 136 & $\mathrm{C}_{10} \mathrm{H}_{16}$ \\
\hline 4 & Sabinene & 8.38 & 976 & 972 & 22.85 & 13.15 & 17.10 & 136 & $\mathrm{C}_{10} \mathrm{H}_{16}$ \\
\hline 5 & $\beta$-Pinene & 8.48 & 981 & 977 & 9.00 & 16.91 & 24.03 & 136 & $\mathrm{C}_{10} \mathrm{H}_{16}$ \\
\hline 6 & Myrcene & 8.62 & 989 & 987 & 7.02 & 4.57 & 5.60 & 136 & $\mathrm{C}_{10} \mathrm{H}_{16}$ \\
\hline 7 & a-Phellandrene & 8.85 & 999 & 1002 & 0.99 & - & - & 136 & $\mathrm{C}_{10} \mathrm{H}_{16}$ \\
\hline 8 & $(+)$-4-Carene & 8.90 & 1009 & 1008 & - & 1.26 & 1.44 & 136 & $\mathrm{C}_{10} \mathrm{H}_{16}$ \\
\hline 9 & a-Terpinene & 9.12 & 1020 & 1014 & 0.54 & - & - & 136 & $\mathrm{C}_{9} \mathrm{H}_{12} \mathrm{O}$ \\
\hline 10 & p-Cymene & 9.24 & 1027 & 1020 & 1.06 & 11.20 & 1.98 & 134 & $\mathrm{C}_{10} \mathrm{H}_{14}$ \\
\hline 11 & Limonene & 9.34 & 1033 & 1024 & 3.00 & 4.50 & 5.27 & 136 & $\mathrm{C}_{10} \mathrm{H}_{16}$ \\
\hline 12 & $\beta$-Trans-ocimene & 9.38 & 1036 & 1031 & 5.32 & 5.47 & 10.98 & 136 & $\mathrm{C}_{10} \mathrm{H}_{16}$ \\
\hline 13 & $\beta$-Cis-ocimene & 9.56 & 1047 & 1044 & 3.73 & 4.09 & 12.92 & 136 & $\mathrm{C}_{10} \mathrm{H}_{16}$ \\
\hline 14 & $\delta$-Terpinene & 9.78 & 1062 & 1054 & 3.11 & 4.30 & 2.62 & 136 & $\mathrm{C}_{10} \mathrm{H}_{16}$ \\
\hline 15 & Cis-sabinene hydrate & 10.02 & 1076 & 1065 & 0.47 & - & - & 154 & $\mathrm{C}_{10} \mathrm{H}_{18} \mathrm{O}$ \\
\hline 16 & Trans-sabinene hydrate & 10.03 & 1090 & 1098 & - & - & 0.86 & 154 & $\mathrm{C}_{10} \mathrm{H}_{18} \mathrm{O}$ \\
\hline 17 & $\begin{array}{c}\text { Norbilan [1-(p-Tolyl } \\
\text { ethanol) }]\end{array}$ & 10.13 & 1099 & 1104 & - & - & 0.31 & 136 & $\mathrm{C}_{10} \mathrm{H}_{16}$ \\
\hline 18 & (-)Terpinen-4-ol & 11.68 & 1190 & 1177 & 1.49 & 1.94 & 1.34 & 224 & $\mathrm{C}_{14} \mathrm{H}_{24} \mathrm{O}_{2}$ \\
\hline 19 & Citronellyl formate & 12.79 & 1274 & 1271 & 0.81 & - & - & 154 & $\mathrm{C}_{10} \mathrm{H}_{18} \mathrm{O}$ \\
\hline 20 & Bornyl acetate & 13.06 & 1293 & 1284 & 31.00 & 14.05 & 8.00 & 184 & $\mathrm{C}_{11} \mathrm{H}_{20} \mathrm{O}_{2}$ \\
\hline 21 & Eugenol methyl ether & 14.4 & 1402 & 1401 & 0.24 & - & & 196 & $\mathrm{C}_{12} \mathrm{H}_{20} \mathrm{O}_{2}$ \\
\hline 22 & Linalyl butyrate & 13.06 & 1400 & 1420 & 0.25 & - & - & 178 & $\mathrm{C}_{11} \mathrm{H}_{14} \mathrm{O}_{2}$ \\
\hline 23 & Methyl iso-eugenol & 14.40 & 1402 & 1461 & -- & 1.65 & - & 178 & $\mathrm{C}_{11} \mathrm{H}_{14} \mathrm{O}_{2}$ \\
\hline 24 & Guaiol & 16.49 & 1560 & 1600 & 1.06 & - & - & 240 & $\mathrm{C}_{16} \mathrm{H}_{16} \mathrm{O}_{2}$ \\
\hline 25 & 7-Methyl-1-naphthol & 17.08 & 1599 & 1620 & - & 0.63 & - & 222 & $\mathrm{C}_{15} \mathrm{H}_{26} \mathrm{O}$ \\
\hline 26 & Dihydro-cis- $\alpha$-copaene-8-ol & 18.12 & 1643 & 1633 & - & 1.01 & 0.78 & 158 & $\mathrm{C}_{11} \mathrm{H}_{10} \mathrm{O}$ \\
\hline 27 & $\begin{array}{c}\text { Capillin [2,4- } \\
\text { hexadyinophenone] }\end{array}$ & 18.14 & 1648 & 1637 & - & 3.16 & - & 222 & $\mathrm{C}_{15} \mathrm{H}_{26} \mathrm{O}$ \\
\hline 28 & $\beta$-Eudesmol & 18.51 & 1667 & 1649 & - & 8.01 & - & 168 & $\mathrm{C}_{12} \mathrm{H}_{8} \mathrm{O}$ \\
\hline \multirow[t]{3}{*}{29} & $\begin{array}{c}\text { p-Toluoin } \\
{\left[4,4^{\prime} \text {-dimethylbenzoin }\right]}\end{array}$ & 15.432 & 1686 & 1790 & 0.12 & 0.63 & - & 222 & $\mathrm{C}_{15} \mathrm{H}_{26} \mathrm{O}$ \\
\hline & \multicolumn{4}{|c|}{ Total number of identified constituents } & 20 & 18 & 16 & & \\
\hline & \multicolumn{4}{|c|}{ Total \% of identified constituents } & 99.00 & 97.63 & 99.9 & & \\
\hline
\end{tabular}

$\mathrm{RI}^{*}$ : Retention indices relative to $\mathrm{n}$-alkanes on SLB-5ms column; $\mathrm{RI}^{* *}$ : Retention indices reported on non polar column; A1, A2 \& A3: samples collected before flowering, and at the beginning and end of the flowering stage. 
Table 3: Antimicrobial activity of essential oil samples of the aerial parts of $A$. monosperma, expressed as diameter of zone of inhibition in $\mathbf{~ m m}$.

\begin{tabular}{ccccc}
\hline Tested microorganisms & \multicolumn{3}{c}{ Tested Samples } & $\begin{array}{c}\text { Standard } \\
\text { Fungi }\end{array}$ \\
A 1 & $\mathrm{~A} 2$ & $\mathrm{~A} 3$ & Amphotericin B \\
Aspergillus fumigatus (RCMB 02564) & $18.3 \pm 0.11$ & $21.3 \pm 0.20$ & $15.6 \pm 0.10$ & $23.7 \pm 0.10$ \\
Candida albicans (RCMB 05035) & $15.4 \pm 0.23$ & $17.8 \pm 0.15$ & $14.1 \pm 0.20$ & $21.9 \pm 0.12$ \\
Geotricum candidum (RCMB 05096) & $21.9 \pm 0.27$ & $23.4 \pm 0.18$ & $16.4 \pm 0.12$ & $26.4 \pm 0.20$ \\
Syncephalastrum racemosum & $\mathrm{NA}$ & $\mathrm{NA}$ & $\mathrm{NA}$ & $25.4+0.16$ \\
(RCMB 05922) & & & \\
Gram-positive bacteria & & & & Ampicillin \\
Staphylococcus aureus (RCMB 010027) & $16.2 \pm 0.28$ & $18.4 \pm 0.44$ & $12.6 \pm 0.18$ & $28.9 \pm 0.14$ \\
Staphylococcus epidermidis (RCMB 010024) & $17.4 \pm 0.37$ & $20.8 \pm 0.25$ & $16.3 \pm 0.35$ & $25.4 \pm 0.18$ \\
Streptococcus pyogenes (RCMB 010015) & $\mathrm{NA}$ & $\mathrm{NA}$ & $\mathrm{NA}$ & $26.4 \pm 0.34$ \\
Gram-negative bacteria & & & & Gentamycin \\
Neisseria gonorrhoeae (RCMB 010076) & $14.4 \pm 0.20$ & $15.2 \pm 0.58$ & $12.3 \pm 0.18$ & $19.9 \pm 0.18$ \\
Proteus vulgaris (RCMB 010085) & $\mathrm{NA}$ & $\mathrm{NA}$ & $\mathrm{NA}$ & $23.4 \pm 0.3$ \\
Klebsiella pneumoniae (RCMB 010093) & $16.8 \pm 0.24$ & $18.3 \pm 0.44$ & $17.1 \pm 0.15$ & $26.3 \pm 0.15$ \\
Shigella flexneri (RCMB 01005420) & $15.2 \pm 0.35$ & $17.4 \pm 0.58$ & $14.1 \pm 0.24$ & $24.8 \pm 0.24$ \\
Escherichia coli (RCMB 010056) & $18.6 \pm 0.19$ & $20.1 \pm 0.25$ & $14.9 \pm 0.15$ & $25.3 \pm 0.18$
\end{tabular}

A1, A2 \& A3: samples collected before flowering, and at the beginning and end of the flowering stage; NA: no action

\section{Evaluation of Antimicrobial Activity Antimicrobial assay}

The antibacterial activity of the essential oils was screened by the agar well-diffusion method, zone of inhibitions being measured in $\mathrm{mm}$, as described by Holder and Boyce (1994). ${ }^{26}$ The essential oils were, separately, tested against the selected strains at concentration of $1 \mathrm{mg} / \mathrm{ml}$. DMSO was used as a negative control; meanwhile Penicillin G and Streptomycin $(10 \mathrm{mg} / \mathrm{ml})$ were used as a positive controls for bacterial strains and Amphotericin B as positive control for fungi. Experiments were carried out in triplicates. Bacterial cultures were incubated at $37^{\circ} \mathrm{C}$, for $24 \mathrm{~h}$ and the fungal ones at $25-30^{\circ} \mathrm{C}$, for 3-7 days. Results are recorded (Table 3 ) as mean zone of inhibition in $\mathrm{mm} \pm$ Standard deviation beyond well diameter $(6 \mathrm{~mm})$ produced on a range of environmental and clinically pathogenic microorganisms using $(1 \mathrm{mg} / \mathrm{ml})$ concentration of tested samples. ${ }^{27}$ Potencies relative to the appropriate antibiotic are represented by the histograms in (Figures 4-6).

\section{Determination of minimal inhibitory concentrations (MIC)}

Broth dilution method ${ }^{28}$ was used for determination of minimum inhibitory concentrations (MIC) of the most active sample. Serial dilutions of each essential oil sample were prepared in DMSO and mixed with broth media in a 96-wells microtiter plate to achieve a final concentration range from $0.003-4 \% \mathrm{v} / \mathrm{v}$. The plates were then inoculated with standardized suspension containing $5 \times 10^{5}$ bacterial count per well. Optical density was measured at $600 \mathrm{~nm}$ after a specified incubation period by means of a JENWAY 6051 colorimeter (U.K.) and was used as a measure of bacterial growth. ${ }^{29}$

\section{Determination of Median Lethal dose $\left(L D_{50}\right)$}

The acute toxicity resulting from oral administration of the volatile oils of the aerial parts of $A$. monosperma Del. was investigated. In this respect, its median lethal dose $\left(\mathrm{LD}_{50}\right)$ was determined according to Karber $(1931)^{30}$ as follows: Preliminary experiments were carried out to determine the minimal dose that kills all animals $\left(\mathrm{LD}_{100}\right)$ and the maximal dose that fails to kill any animal. Several doses at equal logarithmic intervals were selected in between these two doses, and each was orally

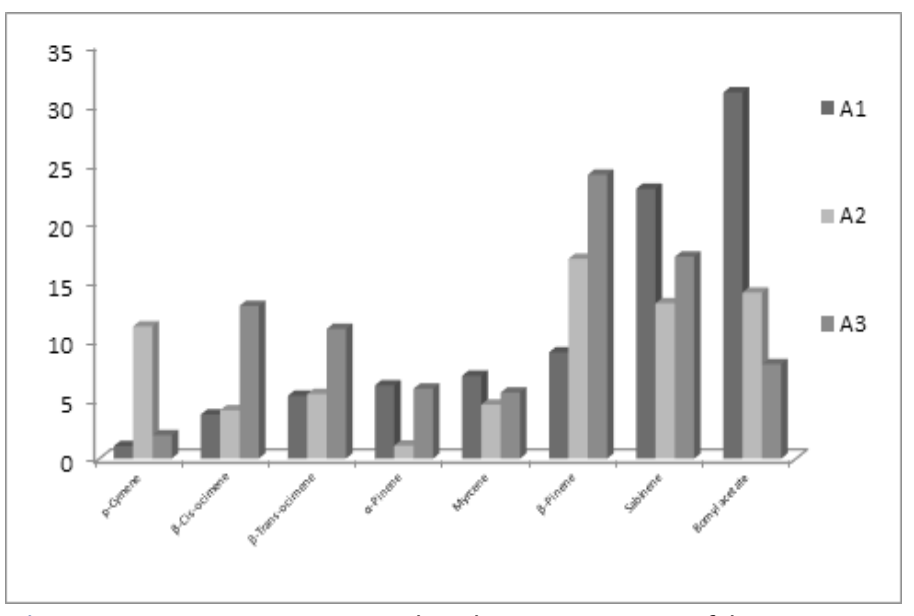

Figure 3: Histogram representing the relative percentages of the major components detected in the essential oils (A1, A2 and A3) samples collected before flowering, and at the beginning and end of the flowering stage of $A$. monosperma, respectively.

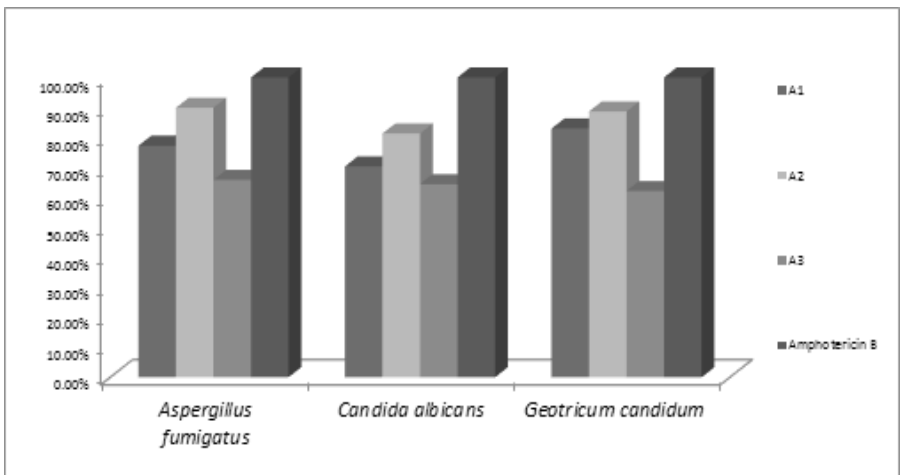

Figure 4: Histogram representing the antifungal activity of essential oils (A1, A2 and A3) samples collected before flowering, and at the beginning and end of the flowering stage of $A$. monosperma, respectively; expressed as potencies as compared to standard Amphotericin B. 
Table 4: Antimicrobial Activity of A2 oil sample* expressed as MICs $(\mu \mathrm{g} / \mathrm{ml})$

\begin{tabular}{|c|c|c|}
\hline Tested microorganisms & MIC & Standard \\
\hline Fungi & & Amphotericin B \\
\hline Aspergillus fumigatus (RCMB 02564) & 0.98 & 0.12 \\
\hline Candida albicans (RCMB 05035) & 7.81 & 0.24 \\
\hline Geotricum candidum (RCMB 05096) & 0.24 & 0.03 \\
\hline Syncephalastrum racemosum (RCMB 05922) & NA & 0.06 \\
\hline Gram-positive bacteria & & Ampicillin \\
\hline Staphylococcus aureus (RCMB 010027) & 7.81 & 0.007 \\
\hline Staphylococcus epidermidis (RCMB 010024) & 0.98 & 0.06 \\
\hline Streptococcus pyogenes (RCMB 010015) & NA & 0.03 \\
\hline Gram-negative bacteria & & Gentamycin \\
\hline Neisseria gonorrhoeae (RCMB 010076) & 31.25 & 3.9 \\
\hline Proteus vulgaris (RCMB 010085) & NA & 0.12 \\
\hline Klebsiella pneumonia (RCMB 010093) & 7.81 & 0.03 \\
\hline Shigella flexneri (RCMB 01005420) & 15.63 & 0.06 \\
\hline Escherichia coli (RCMB 010056) & 1.95 & 0.06 \\
\hline
\end{tabular}

A2 sample of aerial parts collected at the beginning of the flowering stage; NA: no action.

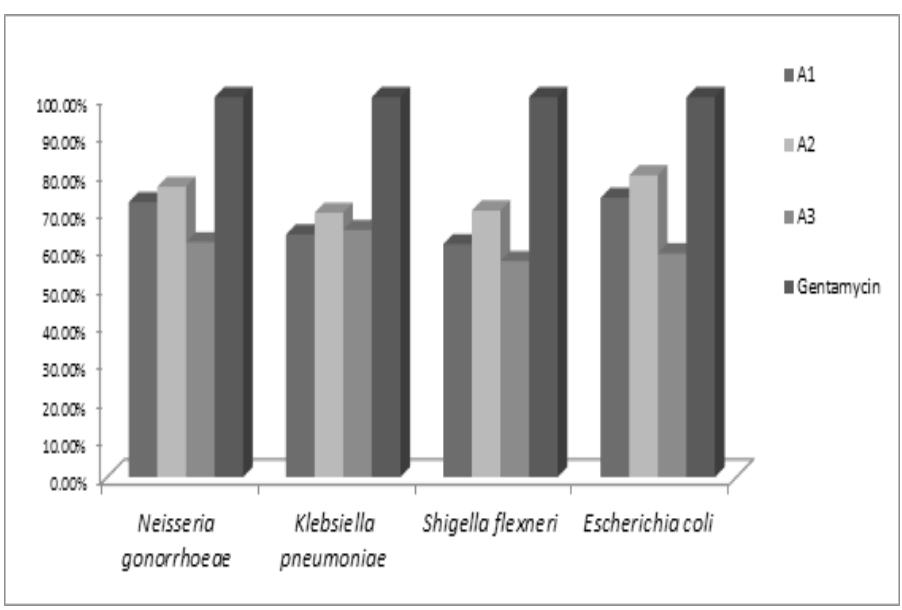

Figure 5: Histogram representing the antibacterial activity of essential oils (A1, A2 and A3) samples collected before flowering, and at the beginning and end of the flowering stage respectively of aerial parts of $A$.monosperma, expressed as potencies as compared to standard Gentamycin.

administered to a group of experimental animals $(n=6)$. The mice were observed for $24 \mathrm{~h}$ and the symptoms of toxicity as well as mortality rates in each group were recorded.

\section{Evaluation of Anti-inflammatory activity}

The acute anti-inflammatory activity was assessed in-vivo by means of the paw swelling, or foot edema method, which is convenient for assessing inflammatory responses to antigenic challenges and irritants. This was performed by examining the ability of the tested samples to reduce or prevent the development of carrageenan-induced paw swelling. This model is commonly used to assess the efficiency of nonsteroidal antiinflammatory drugs (NSAIDs) that inhibit prostaglandin production. ${ }^{31}$

\section{Experimental design}

The method of Winter et al (1962) 32 was adopted. Carrageenan suspension ( $1 \%$ in sterile saline) was prepared, and placed in a refrigerator, at $4^{\circ} \mathrm{C}$ for an overnight, to allow complete hydration of the polysaccharide; then injected $(100 \mu \mathrm{l})$ into the sub-plantar tissue of the right hind paw of Sprague-Dawley male albino rats (120-150 g) to induce edema. Meanwhile, the left hind paw was injected with $100 \mu$ l saline.

The animals were randomized into 5 groups $(n=6)$; one hour before carrageenan injection, they received (by oral administration, p.o.) appropriate doses of the vehicle, tested samples and standard drug, as follows: Group 1 (negative control): received the vehicle (saline, $1 \mathrm{ml} / \mathrm{Kg} \mathrm{b}$. wt.). Groups 2, 3 and 4: received the volatile oil samples $\left(\mathrm{A}_{1}-\mathrm{A}_{3} 0.01 \mathrm{~mL} / \mathrm{kg}\right.$ b.wt., each).

Group 5 (positive control): received the standard anti-inflammatory drug, Indomethacin $(20 \mathrm{mg} / \mathrm{kg} \mathrm{b}$. wt.)

The hind paw diameter was measured by means of Vernier caliper. Measurements were carried out immediately after carrageenan injection, and at selected time intervals ( $1 \mathrm{~h}, 2 \mathrm{~h}, 3 \mathrm{~h}$ and $4 \mathrm{~h}$ ) after drug or samples administration. Experiments were carried out in triplicates. The percentage edema was recorded and percentage edema inhibition calculated as follows:

$\%$ Edema inhibition $=\left(\mathrm{M}_{0}-\mathrm{M}_{\mathrm{t}}\right) / \mathrm{M}_{0} \times 100$,

where: $\quad M_{0}=$ Mean paw diameter of control group at a given time;

$\mathrm{M}_{\mathrm{t}}=$ Mean paw diameter of treated (extract or standard) group at the same time.

\section{Evaluation of the antioxidant activity}

Glutathione (GSH) is an important antioxidant in plants, animals, fungi, and some bacteria, preventing damage to important cellular components caused by reactive oxygen species such as free radicals, peroxides, lipid peroxides and heavy metals. ${ }^{33}$ In healthy cells and tissue, more than $90 \%$ of the total glutathione pool is in the reduced form (GSH) and less than $10 \%$ exists in the disulfide form (GSSG); and an increased GSSG-to-GSH ratio is indicative of oxidative stress. ${ }^{34}$

Various methods have been devised for the determination of glutathione in biological samples, including spectrophotometric- and high-performance liquid chromatography (HPLC)-based techniques. The most popular is the 5,5'-dithio-bis(2-nitrobenzoic acid) (DTNB) spectrophotometric method. ${ }^{35}$ Blood glutathione was determined in Alloxandiabetic rats by adopting the Beutler et al (1963). ${ }^{36}$ The restoration of GSH level reduced due to oxidative stress induced by diabetes was taken as a measure of antioxidant activity.

The principle of the assay depends on that protein and non-protein SH-groups react with Ellman's reagent [5, 5-dithiobis-(2-nitrobezoic acid)] to form the stable yellow colored 5-thio-nitrobenzoic acid, which can be measured at $412 \mathrm{~nm}$.

\section{Experimental design}

Thirty-six adult male albino rats of the Sprague-Dawley strain (120-150 g) were used as experimental animals. Diabetes mellitus was induced by a single intra-peritoneal injection of Alloxan (150 mg/kg b. wt.) followed by an overnight fast. ${ }^{37}$ Hyperglycemia was assessed, after $72 \mathrm{~h}$ of diabetes induction, by measuring the blood glucose levels according to Trinder(1969). ${ }^{38}$

The rats were divided into 6 groups, each of 6 animals $(n=6)$.

The $1^{\text {st }}$ group received $1 \mathrm{ml}$ saline and was kept as a negative control (normal, non-diabetic). Diabetes was induced to the other 6 groups as previously indicated.

Group 2: (Diabetic control) was kept untreated.

Group 3: (Diabetic + Vitamin E, positive control) received the reference drug, Vitamin E (7.5mg/ kg b. wt.).

Groups 4, 5 and 6: (Diabetic + Volatile oils) received $A_{1}, A_{2}$ and $A_{3}(0.01$ $\mathrm{ml} / \mathrm{kg}$ b. wt.), respectively. Experiments were carried out in triplicates. 
Table 5: Results of evaluation of the acute anti-inflammatory activity of the volatile oil samples (A1-A3) of the aerial parts of A. monosperma Del., as compared to Indomethacin

\begin{tabular}{|c|c|c|c|c|c|c|c|c|}
\hline \multirow[b]{2}{*}{ Group } & \multicolumn{2}{|c|}{$1 \mathrm{~h}$} & \multicolumn{2}{|c|}{$2 \mathrm{~h}$} & \multicolumn{2}{|c|}{$3 h$} & \multicolumn{2}{|c|}{$4 h$} \\
\hline & $\begin{array}{c}\% \text { Oedema } \\
\text { Mean } \pm \text { S.E }\end{array}$ & $\begin{array}{l}\% \text { of Oedema } \\
\text { Inhibition }^{\mathrm{b}}\end{array}$ & $\begin{array}{c}\% \text { Oedema }^{a} \\
\text { Mean } \pm \text { S.E }\end{array}$ & $\begin{array}{l}\% \text { of Oedema } \\
\text { Inhibition }^{\mathrm{b}}\end{array}$ & $\begin{array}{c}\% \text { Oedema }{ }^{a} \\
\text { Mean } \pm \text { S.E }\end{array}$ & $\begin{array}{c}\% \text { of } \\
\text { Oedema } \\
\text { Inhibition }^{b}\end{array}$ & $\begin{array}{c}\% \text { Oedema }^{\mathrm{a}} \\
\text { Mean } \pm \text { S.E }\end{array}$ & $\begin{array}{l}\% \text { of Oedema } \\
\text { Inhibition }^{\mathrm{b}}\end{array}$ \\
\hline Control & $4.41 \pm 0.1^{*}$ & - & $4.71 \pm 0.13^{*}$ & - & $4.81 \pm 0.12^{*}$ & - & $4.85 \pm 0.07^{\star}$ & - \\
\hline Al & $4.26 \pm 0.08^{*}$ & 21.36 & $4.19 \pm 0.10^{*}$ & 19.37 & $4.15 \pm 0.05^{*}$ & 18.23 & $3.90 \pm 0.07^{\star}$ & 11.68 \\
\hline A2 & $4.37 \pm 09^{*}$ & 21.72 & $4.30 \pm 0.06^{*}$ & 19.77 & $4.24 \pm 0.07^{*}$ & 18.10 & $4.13 \pm 0.06^{*}$ & 15.04 \\
\hline A3 & $4.31 \pm 0.03^{*}$ & 27.45 & $4.26 \pm 0.02^{\star}$ & 24.56 & $4.22 \pm 0.03^{*}$ & 24.27 & $4.18 \pm 0.01^{*}$ & 20.80 \\
\hline $\begin{array}{l}\text { Indomethacin } \\
(20 \mathrm{mg} / \mathrm{kg})\end{array}$ & $4.16 \pm 0.09^{*}$ & 33.63 & $3.99 \pm 0.06^{\star}$ & 35.07 & $3.92 \pm 0.01^{*}$ & 30.00 & $3.84 \pm 0.01^{\star}$ & 28.54 \\
\hline
\end{tabular}

A1, A2 and A3: volatile oils of aerial parts before, during and at the end of the flowering stage $(0.01 \mathrm{~mL} / \mathrm{kg}) ;$ S.E. $=$ standard error; ${ }^{*}$ Statistically significant from the control normal inflamed group at the corresponding time: $\mathrm{P}<0.05$. Statistical analysis was carried out using repeated measures one way ANOVA followed by Least significant test for multiple comparison. a \% Oedema =wt of right paw-wt.of left paw x 100/wt of left paw; b \%oedema inhibition (\% of change )=(Dc-Dt)x100/ Dc ; Dc is the mean oedema in control rats; Mt is the mean Oedema in drug-treated animals.

Table 6: Effect of volatile oil samples (A1-A3) of the aerial parts of A. monosperma on GHS blood level in Alloxan-induced diabetic rats, as compared to Vitamin $\mathrm{E}$.

\begin{tabular}{ccccc}
\hline Group $(\mathrm{n}=6)$ & Dose / (Kg b.wt.) & $\begin{array}{c}\text { Blood GHS }(\mathrm{mg} \%) \\
\text { Mean } \pm \text { SE }\end{array}$ & a\% Change & belative potency \% \\
\hline Control & - & $36.2 \pm 1.4$ & - & - \\
Diabetic & - & $21.4 \pm 0.5^{*}$ & - & - \\
Diabetic + Vitiamin E & $7.5 \mathrm{mg}$ & $35.8 \pm 1.3^{*}$ & 67.89 & 100 \\
Diabetic + A1 & $0.01 \mathrm{ml}$ & $35.1 \pm 1.3^{*}$ & 64.01 & 94.28 \\
Diabetic +A2 & $0.01 \mathrm{ml}$ & $34.3 \pm 1.2^{*}$ & 60.28 & 88.79 \\
Diabetic +A3 & $0.01 \mathrm{ml}$ & $31.2 \pm 1.1^{*}$ & 45.79 & 67.44
\end{tabular}

GHS: reduced glutathione; A1, A2 and A3: volatile oil of aerial parts before, during and at the end of the flowering stage; * Statistically significant for control group at $\mathrm{P}<0.01$; Statistical analysis was carried out using repeated measures one way ANOVA followed by Least significant test for multiple comparison. a \% Change from control=(Mc-Mt)x100/ Mc ; $\mathrm{Mc}$ is the mean change in control rats; $\mathrm{Mt}$ is the mean change in drug-treated animals. $\mathrm{b}$ \%Relative potency calculated as regard to standard drug.

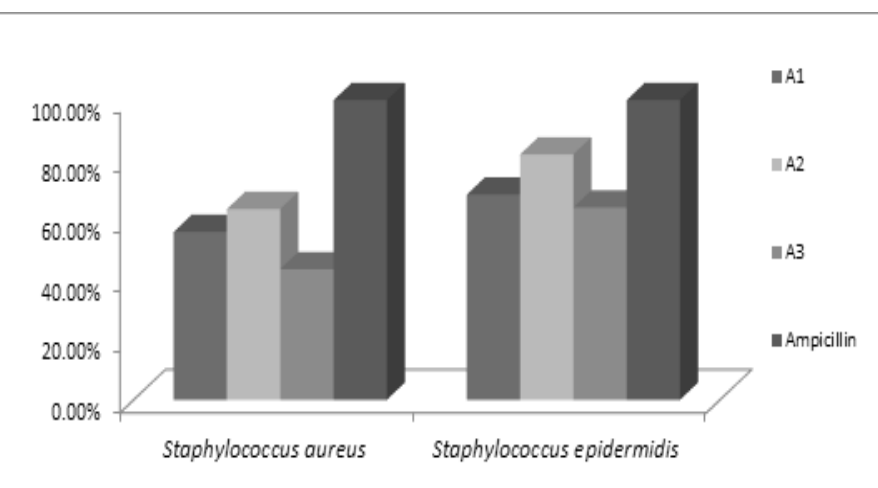

Figure 6: Histogram representing the antibacterial activity of essential oils (A1, A2 and $\mathrm{A} 3$ ) samples collected before flowering, and at the beginning and end of the flowering stage of $A$. monosperma, respectively; expressed as potencies as compared to standard Ampicillin.

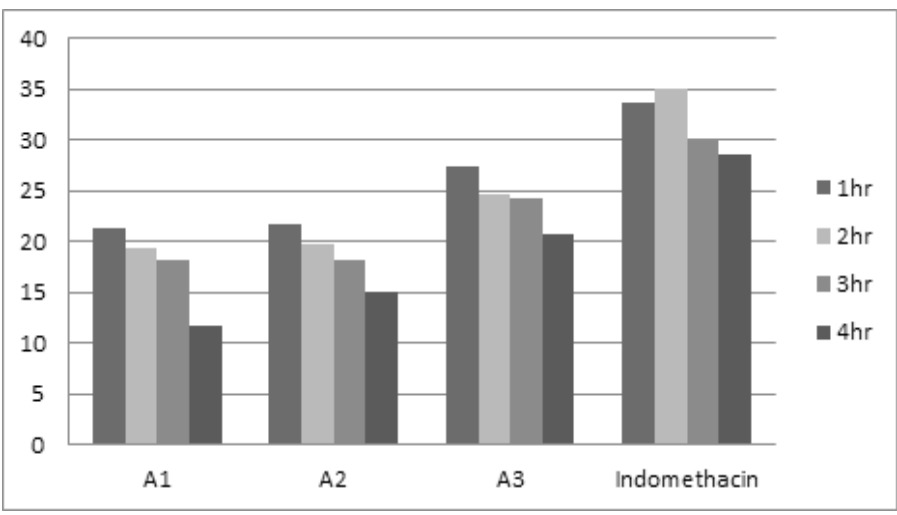

Figure 7: Histogram representing the antiinflamatory activity of essential oils ( $A 1, A 2$ and $A 3$ ) samples collected before flowering, and the beginning and end of the flowering stage of $A$. monosperma, respectively; expressed as potencies as compared to standard indomethacin. 
The blood GSH level was recorded, and percentage change from control computed as follows:

$\%$ Change $=\left(G-G_{0}\right) \times 100 / G_{0}$; where: $G_{0}$ is the GHS level in diabetic animals prior sample administration and $\mathrm{G}$ that measured after.

\section{RESULTS AND DISCUSSION}

\section{Yield and Composition of the Volatiles}

The hydro-distilled volatiles of the aerial parts of A. monosperma, collected before flowering $\left(\mathrm{A}_{1}\right)$, and at the beginning $\left(\mathrm{A}_{2}\right)$ and end $\left(\mathrm{A}_{3}\right)$ flowering stage, were obtained as greenish yellow dextro-rotatory liquids with characteristic odour. Oil yields ranged from 0.16 to $0.26 \% \mathrm{v} / \mathrm{w}$ (on fresh weight basis), the highest being recorded for $\mathrm{A}_{3}$ (Table 1).

Comparative GC profiling revealed a qualitative and quantitative variability among the samples (Tables 2; Figures 1-3). A total of 16-20 components were identified; 11, including 9 non-oxygenated, were common in all the samples. Identified constituents represented 97.63 $99.00 \%$ of the total composition of the analyzed oils.

Samples were noticeably enriched in hydrocarbons; $A_{1}$ and $A_{2}$ showed appreciable and close amounts of these constituents (63.56 and 66.55\%) although distinctly lower than in $\mathrm{A}_{3}$ (88.36\%). Monoterpenoids dominated the group, while sesquiterpenoids were missing and aromatics represented by $p$-cymene only. Sabinene (13.15-22.85\%) and $\beta$-pinene (9.00-24.03\%) were detected in appreciable amounts in all samples and p-cymene mainly in $\mathrm{A}_{2}$ (11.20\%).

Oxygenated components were detected in lesser amounts $(11.29,31.08$ and $35.44 \%$ in $A_{3}, A_{2}$ and $A_{1}$, respectively) being gradually decreased during flowering (highest $\%$ in $\mathrm{A}_{1}$, before flowering). They include esters, alcohols, ketones and phenols. They are mostly terpenoids with few aromatics viz., eugenol methyl ether, methyl iso-eugenol, 7-methyl1-naphthol and capillin. The bicylic monoterpenoid ester, bornyl acetate was the major identified oxygenated compound in all the samples (8.00$31.00 \%$ ) with highest amount in $\mathrm{A}_{1}$ decreasing to about the quarter by time (least in $\mathrm{A}_{3}$ ). Whereas, the sesquiterpenoid alcohol, $\beta$-eudesmol was detected in appreciable amounts (8.01\%) in $\mathrm{A}_{2}$ only. The latter was, in addition, characterized by the presence of capillin (2,4-hexadiynophenone), a phenyl ketonic polyacetylene typically detected in Artemisia species. ${ }^{39}$ Moreover, the chemical profiles of the analyzed Libyan samples were different from those reported for their analogues obtained from plants growing in other localities of close climatic conditions. Among samples collected from Egypt various compounds were detected as major including: 3-methyl-3-phenyl-1,4-pentadiyne, capillene; ${ }^{17}$ dibenzofuran, phenylbicyclo (3.3.1), non-2-en-9-ol benzoate, ${ }^{40}$ 2-pinene-4-one and 3-phenylethyl propenoate. ${ }^{41}$ Meanwhile, $\beta$-pinene and $\alpha$-terpinolene prevailed among components of Saudi leaf and stem essential oils. ${ }^{42}$

\section{Antimicrobial Activity}

The antimicrobial activity of the different samples was evaluated against a set of microorganisms, including 4 fungal and 8 bacterial strains (Table 3 and 4) (Figures 4-6).The tested samples exhibited moderate to remarkable growth inhibitory potential against most of the tested strains as compared to the appropriate standard antibiotics. Yet, all were inactive against the filamentous fungus Syncephalastrum racemosum, the Grampositive bacterium Streptococcus pyogenes and the Gram-negative Proteus vulgaris. Sample $\mathrm{A}_{2}$ demonstrated the highest activity against all affected microorganisms with best efficiency as antifungal, especially on Aspergillus fumigatus (potency, 89.87\% relative to Amphotericin B). In all cases $\mathrm{A}_{3}$ was the least active, except on Klebsiella pneumoniae on which it revealed a slightly higher effect than $\mathrm{A}_{2}$. The potentiality of the oil sample derived from aerial parts collected at the beginning of the flowering stage (sample $\mathrm{A}_{2}$ ) may be attributed to its bornyl acetate content (31\%). ${ }^{43}$

\section{Median lethal dose $L D_{50}$}

The $24 \mathrm{~h} \mathrm{LD}_{50}$ was approximately more than $0.05 \mathrm{ml} / \mathrm{kg} \mathrm{b}$. wt., of the essential oils of the aerial parts. These results showed that the essential oils are safe and non-toxic.

\section{Anti-inflammatory activity}

Results presented in Table 5 and Figure 7 revealed that the $\mathrm{A}_{3}$ volatile sample (hydro-distilled from the aerial parts of the plant collected at the end of the flowering stage) exerted the highest anti-inflammatory activity as compared to the other volatiles obtained from earlier gathered plant material. The sample exhibited a significantly high potency ranging from (70.03-81.62\%) relative to the reference NSAID Indomethacin; and its efficiency appeared the highest after $1 \mathrm{~h}$ of treatment. This remarkable effect could be correlated to its relatively high monoterpenoid content viz., $\beta$-Pinene (24.03\%), Sabinene (17.10\%), $\beta$-trans-Ocimene $(10.98 \%)$ and $\beta$-cis-Ocimene $(12.92 \%)$ with reported anti-inflammatory activity. ${ }^{44}$

\section{Anti-oxidant activity}

The results represented in Table 6 and Figure 8 revealed that the $A_{1}$ (volatiles hydro-distilled from plants collected before flowering) restored the reduced blood GHS level in diabetic animals almost as efficiently as Vitamin E (relative potencies 97.03 and $94.28 \%$, respectively) followed by $\mathrm{A}_{2}$ and $\mathrm{A}_{3}$ (88.79 and $67.44 \%$ ). The antioxidant activity of the volatiles is thus decreased during the flowering stage, being the highest before flowering $\left(\mathrm{A}_{1}\right)$; this could be associated to the decreasing bornyl acetate content of the samples $\left(31.00,14.05\right.$ and $8.00 \%$ in $\mathrm{A}_{1}, \mathrm{~A}_{2}$ and $\mathrm{A}_{3}$, respectively). In fact, both borneol and bornyl acetate are considered as major contributors in the antioxidant activity of essential oils..$^{45,46}$

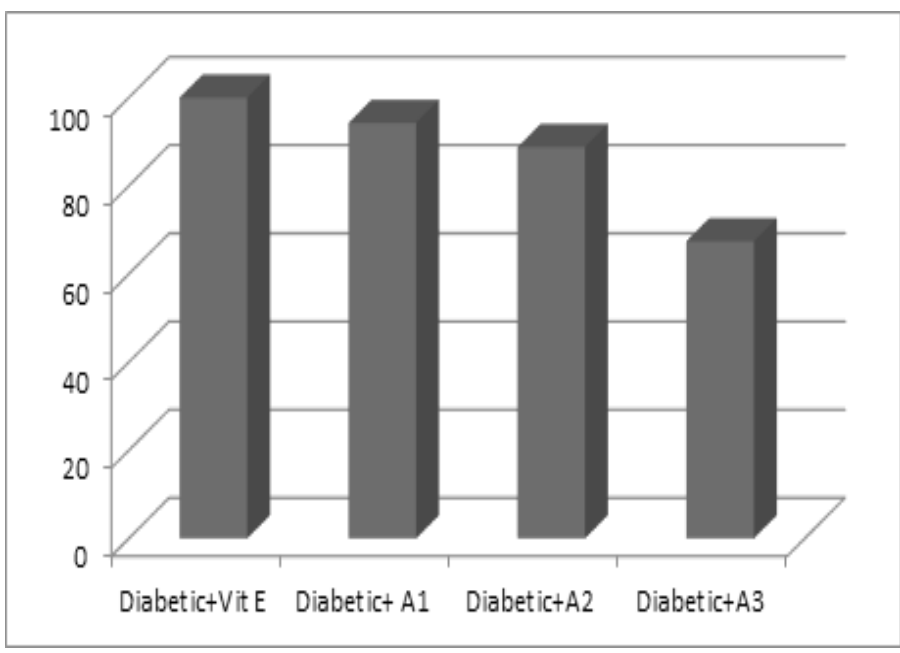

Figure 8: Histogram representing the antioxidant activity of essential oils ( $A 1, A 2$ and $A 3$ ) samples collected before flowering, and the beginning and end of the flowering stage of $A$. monosperma respectively, as potencies as compared to standard vitamin $\mathrm{E}$.

\section{CONCLUSION}

The genotype, ontogenic development and environmental growth conditions of any plant species are known to have a great impact on the qualitative and quantitative composition of its constituents, thus resulting in different chemotypes. In this respect, it was here evident that the stage of development influenced the yield and composition of the hydro-distilled volatiles of the aerial parts of Artemisia monosperma and consequently affected its antimicrobial, anti-inflammatory and antioxidant potencies. The latter could not be exclusively correlated to the efficiency of a 
specific constituent but rather to a synergistic effect of all components. Meanwhile, the difference in composition observed in comparison with samples obtained from other localities may be referred to a number of extrinsic factors which affect growth conditions and consequently the production of secondary metabolites.

\section{ACKNOWLEDGEMENT}

The authors sincerely thank Professor Dr. Mohamed El-Gebaly, Botany Specialist for plants authentication and Dr Marwa Emam Assistant professor at the department Mycology and Biotechnology in Regional Center for Mycology and Biotechnology (RCMB), Al Azhar University, Cairo, Egypt.

\section{CONFLICT OF INTEREST}

The authors report no declarations of interest.

\section{ABBREVIATION USED}

$\mathbf{A}_{\mathbf{1}}$ : Essential oil sample collected before flowering stage; $\mathbf{A}_{2}$ : Essential oil sample collected at beginning of flowering stage; $\mathbf{A}_{3}$ : Essential oil sample collected at end of flowering stage; GC/MS: Gas chromatography / mass spectrometry; Rt: retention times; RI: retention indices; GC/FID: Gas chromatography coupled with flame ionization detector; DMSO: Dimethylsulfoxide; p.o.: per oral; b.wt: body weight.

\section{REFERENCES}

1. Bora KS, Sharma A. The genus Artemisia: A comprehensive review. Pharmaceutical Biology. 2011;49: 101-9.

2. El Nagar EB. Artemisia herba alba and Artemisia monosperma: The Discovery of the first potential Egyptian plant sources for the pharmaceutical commercial production of Artemisinin and some of its related analogues. Journal of Applied Pharmaceutical Sciences. 2012;2:77-91.

3. Fluck $H$, Jaspersen-Schib R. Medicinal plants and their uses (translated from original German and French editions dated 1971 \&1973 by Rowson JM) Foulsham, London. 1976;162-4.

4. Jafri SMH, El-Gadi A. Flora of Libya. Tripoli: Department of Botany, Libya: Al Fateh University; 1987;179-85

5. Chakravarty HL. Plant Wealth of Iraq. A Dictionary of economic plants. Vol. I, Ministry of Agriculture\& Iraq, Baghdad; Agrarian Reform; 1976.

6. Wagner H, Wolff P. New Natural Products and Plant Drugs with Pharmacological, Biological or Therapeutical Activity. New York: Springer-Verlag, Berlin Heidelberg; 1977.

7. Hijazi AM, Salhab AS. Effects of Artemisia monosperma ethanolic leaves extract on implantation, mid-term abortion and parturition of pregnant rats. Journal of Ethno pharmacology. 2010;128:446-51.

8. Al-Soqeer A. Antioxidant activity and biological evaluation of hot-water extract of Artemisia monosperma andCapparis spinosa against lead contamination. Research Journal of Botany. 2011;6:11-20.

9. Saleh MA. An insecticidal diacetylene from Artemisia monosperma. Phytochemistry. 1984;23:2497-98.

10. Maia MF, Moore SJ. Plant-based insect repellents: A review of their efficacy, development and testing. Malaria Journal. 2011;10(1)1-S11.

11. Stavri M, Ford CHJ, Bucar F, Streit B, Hall ML. Williamson RT.et al. Bioactive constituents of Artemisia monosperma. Phytochemistry. 2005;66:233-9.

12. Hammoda FM, Rizk AM, Ismail SI, Hassan NM. Isolation of an acetophenone derivative and coumarins from Artemisia monosperma Del. Fitoterapia. 1978;48:53- 5

13. Hammoda HM, Ela MA, El-Lakany AM, El-Hanbali O, Zaki CS, Ghazy NM. New constituents of Artemisia monosperma Del. Pharmazie. 2008;63:611-4.

14. Saleh NAM, El-Negoumy SI, Abou-Zaid MM. Flavanoids of Artemisia judaica, A. monosperma and A. herba-alba. Phytochemistry. 1987;26 3059-64.

15. Abu-Niaaj L, Abu-Zarga M, Sabri S, Abdalla S. Isolation and biological effects of 7-O-methyleriodictiol, a flavanone isolated from Artemisia monosperma, on rat isolated smooth muscles. Planta Medica. 1993;59:42-5.

16. Elgamal M, Ouf S, Hanna A, Yassin F. Phytochemical and mycological investigation of Artemisia monosperma. Folia Microbiologica. 1997;42:203-10.

17. Saleh MA. Volatile components of Artemisia monosperma and A. judaica growing in the Egyptian deserts. Biochemical Systematics and Ecology. 1985;13:265-9.
18. Bohlmann F, Ehlers D. Einneues p-hydroxyacetophenon-derivataus Artemisia monosperma. Phytochemistry.977;16:1450-1.

19. Zaki D, Abd El-Aziz M, El-Gengeihy S, Morsi N. Antimicrobial potentiation of some Egyptian desert plant. Herba Hungarica. 1984;23:73-84.

20. Zaki M, Mathew KT, Gibson T, Williamson RT, Gibbons S. New constituents of Artemisia monosperma. Journal of Natural Products. 2004;67:892- 894.

21. NIST, NIST Chemistry WebBook: NIST Standard Reference Database Number 69 Available: http://webbook.nist.gov/chemistry/ accessed 14 March ; 2012.

22. McLafferty FW, Stauffer DB, Stenhagen E, Heller SR In: McLafferty FW, Stauffer DB [eds.], The Wily/NBS Registry of Mass Spectral Data, $1^{\text {st }}$ edn. USA, New York: Wiley; 1989.

23. Adams RP. Identification of Essential Oils components by Gas Chromatography/ Mass Spectroscopy, $4^{\text {th }}$ edn. Allured Publ. Crop, Carol stream, IL; 2007.

24. Woerdenbag HJ, Lüers JFJ, Uden W, Pras N, Malingré TM, Alfermann AW. Production of the new antimalarial drug artemisinin in shoot cultures of Artemisia annua L. Plant Cell Tissue. Organ Culture. 1993;32:247-57.

25. Pala-Paul J, Perez-Alonso MJ, Velasco-Negueruela A, Ramos-Vazquez $P_{1}$ Gomez-Contreras F, Sanz J. Essential oil of Santolina rosmarinifolia L. ssp. rosmarinifolia:firstisolation of capillene, adiacetylenederivative. FlavourFragranceJ. 1999;14:131-4.

26. Holder IA, Boyce STAgar well diffusion assay testing of bacterial susceptibility to various antimicrobials in concentrations non-toxic for human cells in culture. Burns. 1994;20:426-69.

27. Gumgumjee NM, Khedr A, Hajar AS Antimicrobial activities and chemical properties of Tamarindus indica L. leaves extract. African Journal of Microbiology Research. 2012;6:6172-81.

28. NCCLS National Committee for Clinical Laboratory Standards. Methods for Dilution. Antimicrobial susceptibility test for bacteria that grow aerobically- $3^{\text {rd }}$ ed., Approved standard, M7-A3.13(25), NCCLS, Villanova, PA;1993.

29. Clinical and Laboratory Standards Institute. Methods for dilution antimicrobial susceptibility tests for bacteria that grow aerobically. Approved standard M07-A6. Clinical and Laboratory Standards Institute, Wayne, PA; 2003.

30. Karber $G$. Determination of $L D_{50}$. Archives of Experimental Pathology and Pharmacology. 1931;62:480-3.

31. Whiteley PE, Dalrymple SA. Models of Inflammation: Carrageenan-Induced Paw Edema in the Rat. Current Protocols in Pharmacology. 00:5.4:5.4.1-5.4.3. onlinelibrary.wiley.com; 2001.

32. Winter GA, Risley EA, Nuss GW. Carrageenan-induced oedema in hind paw of the rat as an assay for anti-inflammatory drugs. Proceedings of the Society of Experimental Biology and Medicine. 1962;111:544-7.

33. Pompella A, Visvikis A, Paolicchi $A$, Tata $V$, Casini AF. The changing faces of glutathione, a cellular protagonist. Biochemical Pharmacology. 2003;66:1499-503.

34. Halprin K. The Measurement of Glutathione in Human Epidermis using Glutathione Reductase. Journal of Investigative Dermatology. 1967;48:149-52.

35. Rahman I, Kode A, Biswas SK. Assay for quantitative determination of glutathione and glutathione disulfide levels using enzymatic recycling method. Nature Protocols. 2006;1:3159-65.

36. Beutler E, Duron O, Kelly B. Improved method for the determination of blood glutathione. Journal of Laboratory and Clinical Medicine. 1963;61:882-8.

37. Eliasson SG, Samet JM. Alloxan-induced neuropathies lipid changes in nerve and root fragments. Life Sciences. 1969;8:493-6.

38. Trinder P. Estimation of serum glucose and triglycerides by enzymatic method Annals of Clinical Biochemistry. 1969;6:24-7.

39. Whelan LC, Ryan MF. Effect of polyacetylenecapillin on human tumor cell lines Anticancer Research. 2004;24: 2281-6.

40. Hifnawy MS, Abdel Wahab SM, El-Hawary SS, Karawya MS. Study of essential oil of Artemisia monosperma and its larvacidal effects. International Journal of Crude Drug Research. 1990;28:247-51.

41. Soliman MM. Phytochemical and toxicological studies of Artemisia L. (Compositae) essential oil against some insect pests. Archives of Phytopathology and Plant Protection. 2007;40:128-38.

42. Khan M, Mousa AA, Syamasundar KV, Alkhathlan HZ. Determination of chemical constituents of leaf and stem essential oils of Artemisia monosperma from central Saudi Arabia. Natural product communication. 2012;7:1079-82.

43. Letchamo W, Ward W, Heard B, Heard D. Essential oil of Valeriana officinalis $L$ cultivars and their antimicrobial activity as influenced by harvesting time under commercial organic cultivation. Journal of Agriculture Food Chemistry. 2004;16:3915-9.

44. de Cássia da Silveira e Sá R, Andrade LN, de Sousa DP. A Review on AntiInflammatory Activity of Monoterpenes. Molecules. 2013;18:1227-54.

45. Horváthováa E, Slamenováa D, Maršálkováa L, Šramkováa M, Wsólováb L. Effects of borneol on the level of DNA damage induced in primary rat hepatocytes and testicular cells by hydrogen peroxide. Food and Chemical Toxicology. 2009;47:1318-23.

46. Rice-Evans C, Miller N, Paganga G. Antioxidant properties of phenolic compounds- Review. Trends in Plant Science. 1997;2:152-9. 
GRAPHICAL ABSTRACT

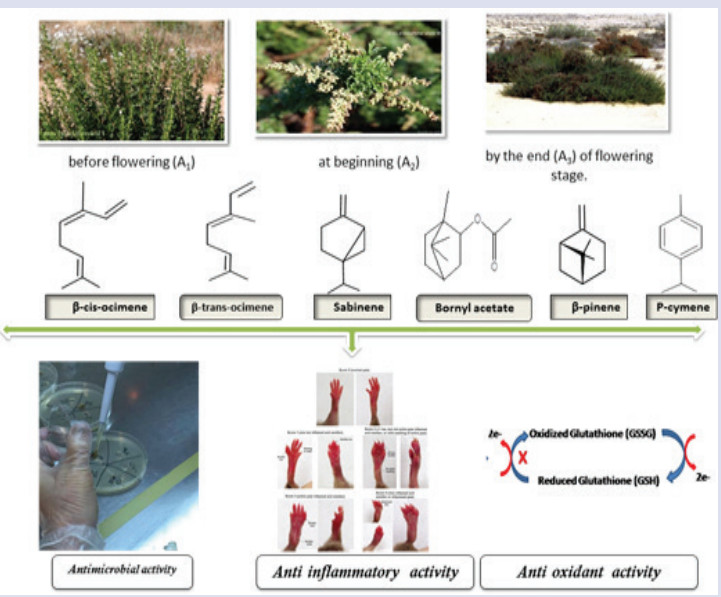

\section{ABOUT AUTHORS}

\section{SUMMARY}

The genotype, ontogenic development and environmental growth conditions of any plant species are known to have a great impact on the qualitative and quantitative composition of its constituents, thus resulting in different chemotypes. In this respect, it was here evident that the stage of development influenced the yield and composition of the hydrodistilled volatiles of the aerial parts of Artemisia monosperma and consequently affected its antimicrobial, anti-inflammatory and antioxidant potencies. The latter could not be exclusively correlated to the efficiency of a specific constituent but rather to a synergistic effect of all components. Meanwhile, the difference in composition observed in comparison with samples obtained from other localities may be referred to a number of extrinsic factors which affect growth conditions and consequently the production of secondary metabolites. The remarkable anti-inflammatory effect could be correlated to its relatively high monoterpenoid content viz., $\beta$-Pinene $(24.03 \%)$, Sabinene $(17.10 \%)$, $\beta$-trans-Ocimene $(10.98 \%)$ and $\beta$-cis-Ocimene (12.92 $\%$ ) with reported anti-inflammatory activity. The $A_{1}$ (volatiles hydro-distilled from plants collected before flowering) samples restored the reduced blood GHS level in diabetic animals almost as efficiently as Vitamin $E$ (relative potencies 97.03 and $94.28 \%$, respectively) followed by $A_{2}$ and $A_{3}$ (88.79 and $67.44 \%$ ). The antioxidant activity of the volatiles is thus decreased during the flowering stage, being the highest before flowering $\left(A_{1}\right)$; this could be associated to the decreasing bornyl acetate content of the samples $\left(31.00,14.05\right.$ and $8.00 \%$ in $A_{1}, A_{2}$ and $A_{3}$, respectively). In fact, both borneol and bornyl acetate are considered as major contributors in the antioxidant activity of essential oils.
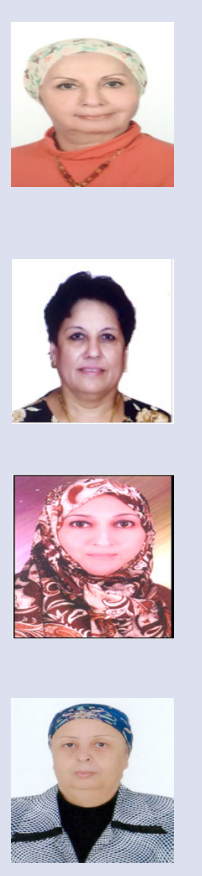

Soheir Mohamed El Zalabani, Ph.D., Professor of Pharmacognosy, Department of Pharmacognosy, College of Pharmacy, Cairo University, Cairo Egypt. Email: soheir.elzalabani@pharma.cu.edu.eg

Field of specialization: Phytochemical investigation of plants and related drugs of biological origin; isolation and identification of plant constituents; evaluation of drugs for commercial production and industrialization; determination of quality and standardization of natural products; morphological and microscopical examination of vegetable drugs; application of new technologies in formulation of natural products

Soad Hanna Tadros, Ph.D., Professor of Pharmacognosy, Department of Pharmacognosy, College of Pharmacy, Cairo University, Cairo Egypt. Email: soad_Hanna@yahoo.com

Abeer Mohamed ElSayed, Ph.D.,Associate professor of Pharmacognosy, Pharmacognosy Department, College of Pharmacy, Cairo University, EGYPT. Email:abeer.ali@pharma.cu.edu.eg.

Field of specialization: Pharmaceutical sciences is my major field of specialization, while the minor one is natural products chemistry, botany and medicinal plants and herbal alternative medicine.

Amany Amen Sleem PH.D., Professor of pharmacology, Pharmacology Department, National Research Center, El-Dokki, Giza, EGYPT

Areej Almaktouf Daboub MSc. of pharmacognosy, Department of pharmacognosy, College of pharmacy, AL ZawiaUniversity, LIBYA.

Cite this article: El Zalabani SM, Tadros SH, El Sayed AM, Daboub AA and AmenSleem A. Chemical Profile and Biological Activities of Essential oil of Aerial parts of Artemisia monosperma Del. Growing in Libya. Pharmacog J. 2017;9(4):577-86. 